\title{
Gender inclusion and horizontal gender segregation: stakeholders' strategies and dilemmas in Swedish teachers' education
}

\author{
Susanne Kreitz-Sandberg
}

\section{Linköping University Post Print}

\section{Tweet}

N.B.: When citing this work, cite the original article.

This is an electronic version of an article published in:

Susanne Kreitz-Sandberg, Gender inclusion and horizontal gender segregation: stakeholders' strategies and dilemmas in Swedish teachers' education, 2013, Gender and Education, (25), 4, 444-465.

Gender and Education is available online at informaworldTM:

http://dx.doi.org/10.1080/09540253.2013.772566

Copyright: Taylor \& Francis (Routledge)

http://www.routledge.com/ 
Gender Inclusion and Horizontal Gender Segregation: Stakeholders'

Strategies and Dilemmas in Swedish Teachers' Education

Susanne Kreitz-Sandberg

Department of Behavioural Science and Learning, Linköping University, Linköping,

Sweden

Dr Susanne Kreitz-Sandberg

Linköping University

Department of Behavioural Science and Learning

58183 Linköping

Sweden

E-mail: susanne.kreitz-sandberg@liu.se 
This paper contributes to our knowledge of teacher educators' strategies for, and dilemmas with, working with gender inclusion in teachers' education. It illustrates how gender is constructed and reconstructed in teachers' education. The study revealed that teachers' education is not only - as earlier described - a highly feminised field, it is also a discipline that is permeated by horizontal and vertical segregation typical of higher education. The study analyses how university teacher educators experience and handle consequences of this horizontal segregation, building on interviews with subject representatives at a Swedish university. The results exemplify how university teachers reflect on gender policies and their own roles when working with teacher students. Heteronormative patterns also become visible in strategies meant to facilitate gender equality and desegregation. The author argues for the need to include university teachers' perspectives in future strategies for developing gender inclusion in university education.

Keywords: teacher education; gender inclusion; horizontal gender segregation; gender mainstreaming; dilemma; higher education

\section{Introduction}

Developing sustainable structures for gender equality depends on the commitment of all actors. While gender mainstreaming is characterised by top-down approaches, with global, national, and local agencies setting rules and deciding on policies for increased gender equality (e.g., HSV 2005; Eurydice 2010), gender inclusion is based on the perspectives and involvement of the actors, such as, in this case, university teacher educators. While gender mainstreaming is a political tool, gender inclusion aims at the pedagogical dimensions of realising gender equality policies. This concept is based on a need to reach out to all university teacher educators with the aim of working for gender equality in university studies.

This paper explores university teacher educators’ perceptions of gender policies and their own roles when working with teacher education students. It aims to contribute to research on gender, on teacher education, and on higher education. Teacher education 
has been portrayed as a feminised field as well as a hierarchical and gendered workplace (Maguire and Weiner 1994; Dillabough and Acker 2002; Murray and Maguire 2007). Weiner argues that the 'gendered nature of teaching, schools and teacher education needs to be better understood, challenged and changed' (2002, 282). Gender issues emerge as central topics within Swedish teacher education (Erixon Arreman 2005; Erixon Arreman and Weiner 2007). Programmes for teaching younger children are chosen almost exclusively by women, while there is more of a balanced gender distribution in programmes for upper secondary school teachers. The gender balance varies across different subjects, with more men studying and teaching in natural sciences and some social sciences while, for example, languages are more typical subjects for women (Hjalmarsson 2009).

\footnotetext{
Men and women teacher educators are likely to have different occupational roles: with men more orientated to teaching secondary student teachers and in the socalled harder science subjects, and women, to teaching student teachers of younger children, and in 'caring' and arts subjects. Moreover, career structures tend to favour men, in terms of status, pay, intensity of work levels as well as influence on decision making. (Erixon Arreman and Weiner 2007, 332)
}

This distribution of roles is closely connected to the gender contract existing in society (Hirdman 1988, 2007). Teacher education is an outstanding example for describing and analysing horizontal segregation and other aspects of the gender order in higher education. Strategies in tackling gender issues in Swedish higher education range from gender mainstreaming and policies for gender-sensitive pedagogy (Bondestam 2004) to including post-structural feminist thinking into teachers’ education (Lenz Taguchi 2005). In some universities solutions are sought in specific pedagogical practices and in teaching students feminist theory, such as introducing norm-critical perspectives, as well as an understanding of intersections of norms about nationality, sexuality, and 
ethnicity as topics for teacher training (Reimers 2006). The Swedish National Agency for Higher Education encourages and funds projects that challenge teacher educators in their pedagogical work to move towards more gender equality in teachers’ education (Lykke 2010; Hedlin and Åberg 2011a, 2011b).

This article argues for the need to reconsider strategies for gender mainstreaming in higher education. It introduces the term gender inclusion to characterise a new set of working for gender equality in teacher education. Although a lot of research on gender mainstreaming in higher education is being done, we know little about how university teachers reflect on gender policies and their own role when working towards gender inclusion in their interaction with teacher students. The purpose of this study is to describe university teachers' perceptions of strategies and dilemmas when working with gender inclusion in teachers' education. This will contribute to understanding how gender structures and gender culture are reproduced in universities in general and teacher education in particular.

\section{Theoretical frameworks}

In publications on gender and education, we are often confronted with a paradox:

Despite the perception of gender as fluid and active, the materiality of practice cannot be denied; for example, in the sense that, teachers' practices are influenced by local cultures, identities and material conditions. This paradox - gender as fluid but at the same time a social structuring mechanism - is a much debated issue among feminist researchers. (Nyström 2007, 6, italics by article’s author)

This study shares a perspective of gender as dynamic and dependent on contexts and processes (Connell 1995). This includes possibilities for change, without ignoring social hegemonic conditions and division of power. Gender is not seen as a personal trait but one that is developing in the process of interaction, as has been described both in feminist studies and in critical studies on masculinity. 
Gender is seen as a category being constantly constructed and re-constructed in the search for identity (Butler 1990; Lykke 2009). Concepts of doing gender have frequently been applied in studies of gender and education. Furthermore, intersectional perspectives, which see gender as developing in interaction with other social categories like class, ethnicity, sexuality, or generation (de los Reyes and Mulinari 2005, Lykke 2009), allow for a more complex understanding of the diversity of conditions and situations, structures and practices in educational processes.

Educational institutions are important arenas for the construction and reconstruction of norms in general and of a heteronormative order in particular. Bromseth (2010) draws on Judith Butler with her definition of heteronormativity, as based on the principle of hierarchical differences, with certain persons (bodies and lifestyles) being privileged while others are systematically and by repetition presented as deviant, less desired, and less valuable. Heteronormativity forms an applicable framework for a critical analysis of teachers’ education (Reimers 2006).

\section{Gender segregation, gender neutrality, and gender difference}

The term horizontal gender segregation stands for the division in disciplines that are dominated or preferably chosen by women or men. Vertical gender segregation describes pyramid-shaped hierarchies: the higher a position, the fewer women - a situation often visualised as a glass ceiling, which is difficult to break through. Both vertical and horizontal segregation contribute to a specific gender order within universities (Husu 2000, 2001). Husu describes aspects of such sometimes-hidden gender discrimination in academia and science. Universities are not gender neutral; gender dynamics and respective communication structures influence formal and informal networks, as well as teaching structures. Differences can be found in academic cultures, the recruitment of staff and the division of labour within the institutions that 
can be discriminatory in nature; parental leave is shared, not equal, and sexual harassment issues still persist (HSV 2005). Gender structures and gender culture are reproduced in universities as they are in many other organisations. Husu argues, as the main author in a report by the Swedish National Agency for Higher Education on hidden gender discrimination (HSV 2005), for analysing universities and science from a gender perspective in order to critically investigate the claimed gender neutrality.

According to Lahelma (2011) and results from research on gender in teacher education in Finland, there are a variety of interlinked difficulties in successfully integrating - or including - a gender perspective into teachers' education. These are, for example: difficulties within the concepts around gender, equality, and difference; the myth of having already achieved gender equality; the involvement of gender issues in personal lives and subjectivities, as well as an already packed curriculum (Lahelma 2005, 2006, 2011). Difficulties within the concepts around gender, equality, and difference are related to what Ronkainen and Lempiäinen have earlier called 'genderless gender' or gender neutrality, which is often understood as gender equality (Lahelma 2011). It is connected to a gender-neutral rhetoric by which people are treated as persons in their own right, without gender. Gendered structures, processes, cultures, and subjectivities are taken for granted. It has been argued, however, that gender differences have to be taken into account, as well. Interestingly, both concepts, the one of gender neutrality and the other of gender differences, can be found simultaneously in administrative texts on gender equality. Gender neutrality often ignores actual gendered structures and choices, and gender differences are often understood in an essentialist way, 'based on the assumption that girls and boys belong to two groups that differ from each other' (Lahelma 2011, 268). This is often repeated like a mantra, without concretisation, and linked to broad and generalising worries. 
Some authors have critically described so-called 'travelling discourses’ of boys' poor achievement and a lack of male teachers, targeting simplified statements of boys’ worse results in relation to a feminised school and insufficient support for boys. The authors see a danger of over-simplification within these globally circulating discourses and want to remind us about the importance to stay aware of the complexity of discrimination and the possibility of variation in different national and local school contexts (Lahelma 2005; Arnesen, Lahelma, and Öhrn 2008).

Tinklin et al. (2003) describe why simple, biological explanations are inadequate when monitoring inequalities in schools and beyond. Culturally defined gender and a biologically determined sex are interlinked, and gender differences among and within boys’ and girls’ groups must be taken into account:

Any discussion of inclusion should always pay attention to the gender dimension and the interactions between gender, social class and ethnic background. In spite of the advances made by females in school education, there are plenty of ways in which females continue to be disadvantaged in school education and beyond. (Tinklin et al. 2003, 650)

The authors warn against viewing boys and girls together as a homogenous group and remind us that heteronormative and stereotyped expectations, attitudes, and behaviour are more likely to be reinforced, rather than challenged in pedagogical practices, even if this happens in the context of inclusion.

\section{Gender in the Swedish education system}

Sweden, together with a number of other Nordic countries, has long been seen as a leader in gender equality. Gender and education is an extended research field in Sweden and other Nordic countries, and gender-related topics have already been investigated for decades (Wernersson and Ve 1997). There are a series of comprehensive bibliographies 
on gender and school in Sweden and other Nordic countries (Öhrn 2002; Wernersson 2006; Nyström 2009). Recently, Carlberg and Bondestam (2010) have compiled almost 1,500 references in a bibliography of Swedish research publications on gender and education for the period from 1969 to 2009. Bondestam (2010) describes in his secondary analysis of these studies that two dichotomous gender categories are mostly already assumed, which contributes to an imminent risk that this division recreates the problem that gender equality work intends to solve.

Seventy per cent of the 160000 persons working in the Swedish school and adult education system were women in 2010/11. Most of them work in primary and secondary schools. Gender distribution is uneven in almost all areas, except in upper secondary schools. In preschool classes only 6 per cent of the teachers are men and 94 per cent are women. In primary schools (grades 1-6) 76 per cent of the teachers are women and 24 per cent are men. In upper secondary schools about half of the teachers are men and half of them are women (Skolverket, 2011). Statistics from the Swedish National Agency for Education show a significant increase in women in head teacher positions in upper secondary schools. While in 1993/94 about 27 per cent of the head teachers were women, in the fiscal year 2010/11 the figure was 42.2 per cent. ${ }^{1}$ This illustrates that the vertical segregation between different fields and age groups still prevails, but that the number of women in school management is increasing.

\section{Women and men in Swedish secondary education}

Sweden is one of the countries where not only vertical but also horizontal segregation is being problematised. Young women and men choose different programmes in secondary school. Professional upper secondary schools are especially segregated, while the distribution between men and women is more even in academic oriented schools, with the exception of technical programmes. This general distribution has not changed 
significantly during recent decades, although a more equal gender distribution has been promoted since the 1990s (Sandell 2007).

The most even distribution statistics are found in natural science programmes, with 45 per cent women and 55 per cent men. However, only around 15 per cent of students attend upper secondary schools where the distribution is in a 40-60 per cent range. If we also include programmes with up to 65 per cent in the definition of gender equal distribution, half of all upper secondary school students study gender homogeneous programmes and the rest gender segregated ones. Some obvious changes have however occurred in highly gender homogeneous programmes. In the 1980s, 30 per cent of all young men studied a programme attended by at least 90 per cent men, and the corresponding number for women was 21 per cent (Wernersson 1991, cited by Sandell 2007). In 2005/06, technical professional upper secondary schools were still similarly dominated by men, but in upper secondary schools for caring, which were previously completely dominated by women, the percentages of men as students has risen (Sandell 2007). This shows that traditionally feminised fields have been opened up to men, while the technical branches of Swedish secondary education are still mostly studied by men only.

\section{Gender in Swedish higher education}

Gender distribution varies between different fields of research, according to statistics for Swedish higher education. Although the distribution is in a 40 to 60 interval in seven out of twelve research areas, more than two thirds of employees in teaching and research are men in technical fields while there are more women in some others, for example in caring sciences (SCB 2010). Besides this horizontal segregation, vertical segregation exists between different employment forms with an almost equal gender distribution in positions as university teachers but more men in research-intensive 
positions and higher up in the university hierarchy. The numbers of women as professors are rising, but at 21 percent in 2010 are still low (SCB 2010).

\section{Gender segregation and employment in Sweden and other European countries}

Causes of gender segregation in employment have been studied since the 1970s (see e.g. Anker 1997, Bridges 2003, Bielby and Reskin 2005, Bettio 2008). Obviously there can be no single-factor explanations. Different preferences of subjects and contents in education, training and occupation, prejudice according to male and female employment, the need to combine occupational work with caring tasks and finally barriers in personal management in the employment sector are the most relevant arguments. Segregation leads - not necessarily, but often - to differences in payment and an undervaluation of women's work.

European comparative studies show that a significant increase in female employment is likely to raise the level of horizontal segregation in the short and medium terms. Desegregation can occur then as a second step towards a more gender equal employment situation. In the 1990s, Sweden - along with other Nordic countries - was known for strong gender segregation. In recent decades, however, a variety of programmes have contributed to desegregating effects in the overall employment situation. Together with Norway, Denmark, the UK, Austria and the Czech Republic, Sweden experienced a relatively fast desegregation between 1997 and 2007 (EGGE 2009). According to EGGE (2009), the latest research suggests three priorities for policy development: reconciliation of provisions for employment and family life; working towards changes in attitudes, choices and competences not only of women but also of men; and finally, more investigation into internal work and practices in employment and educational organisations in order to develop structural preconditions for desegregation. 


\section{Qualitative interviews as a research method}

This study is exploratory in nature. Although we know that university teacher education is perpetuated by horizontal and vertical gender segregation, we know little about how teacher educators perceive this segregation, what they describe as their own contribution to gender mainstreaming and which mechanisms for reproducing gender in teacher education are relevant in relation to the often described gender segregation. The study is based on qualitative interviews with low structure (Bryman 2008) in order to explore university teacher educators' perceptions of gender policies and their own roles when working with teacher education students. The focus is on the interview as a conversation (Kvale and Brinkman 2009), which becomes evident as a low structure allows the interview partners strong influence in terms of shaping topics and highlighting specific aspects in relation to the purpose and questions mentioned in the information letter concerning the university teachers' actual work, purposes, and aims for the development of gender perspectives in the respective subject. The study does not aim to represent teacher educators’ perspectives generally, but aims - in association with post-structural views by Derrida and Parker - to deconstruct meaning, which is often taken for granted, hidden, or suppressed (Henwood 1997).

\section{The local research context}

This study was carried out at a medium-size, multi-faculty university founded during the expansion phase of Swedish higher education in the 1960s. The university has four faculties and 14 departments with close to 30,000 students and 4,000 employees. Teacher education is oriented towards pre-school, pre-school class, leisure-time centre, compulsory school, upper secondary school, and vocational education. The programmes are located at two campuses. There were 2.750 students studying in different teacher 
education programmes when the study was carried out in 2009/2010. During the first year, students of all programmes studied educational science courses. After completing these courses, they enter studies relevant to their teaching orientation. In the presented study, it is teacher educators who are responsible for this variety of about 30 different subjects who were interviewed. With 17 men and 13 women, this area of teacher education is a well-balanced field in terms of gender.

In the Faculty of Arts and Science and the Faculty of Educational Science, 49\% of faculty were women. Female lecturers (university teachers without a Ph.D.) accounted on average for 57\%, senior lecturers (with a Ph.D.) for 49\%, and professors for 24\% (LiU 2010a). Gender equality and gender issues are covered in the Equal Opportunities Strategy and Action Plan (LiU 2011). The university’s action programme for gender equality is based on a concept of gender that includes the beliefs that exist in society with regard to what is defined as feminine and masculine, and that gender arises from an interaction between biological sex and the human social and cultural environment. Gender is thus seen as changeable in connection with the gender order, which determines the distribution of information and resources between the sexes. According to university documents, one has to take into account that male gender is structurally superior to female gender in today’s society (LiU 2009) and corresponding power relations.

\section{Inclusive gender perspectives}

A gender perspective is immanent and explicit in many of the university’s programmes. After completing their education, students should have acquired knowledge and an understanding of the influence exerted by sex and gender at the individual and societal levels, so that they benefit from this knowledge in their future working lives. Every faculty is responsible for a so-called gender lectureship. A gender lecturer is a 
researcher who works with the integration of gender issues within educational programmes on a part-time basis. This shall provide resources, competence, and credibility to the work with long-term and sustainable gender mainstreaming and contribute to gathering and documenting experiences (LiU 2010b).

One of the basic ideas of working with gender inclusion at the university is that different situations require diverse solutions:

Gender mainstreaming is possible within every subject, the question is simply how. According to our experiences, different strategies are appropriate on different occasions. If you cannot integrate a gender perspective within the content of education, you can always work with the form of education. (LiU 2010b, 4)

A gender perspective, or gender as content, covers areas like knowledge, and an understanding of the influence exerted by sex and gender at the individual and societal levels. Taking gender into account in relation to the form of education aims to provide education 'in such a way that men's and women’s experience and knowledge are clarified and developed. Gender sensitivity in practice is important to counteract unequal power relationships between women and men’ (LiU 2010b, 3). This kind of gender-sensitive teaching in higher education is based on a perspective of unequal power relations in society as a whole, which can also influence teaching processes. Responding strategies and respective class management tools can be applied in all lessons, without consideration for the content of teaching (Bondestam 2004; Fogelberg Eriksson and Karlson 2006). It becomes equally or perhaps even more important in technical fields as within the humanities or educational and social sciences.

The university values pro-active gender policies in the context of a diversity approach, where equal opportunities are promoted with a focus on equality and gender, ethnic and religious diversity, accessibility and participation for people with disabilities, and equality of rights and treatment for all, regardless of age or gender identity (LiU 
2011). A frequent claim for the university’s annual report is to provide information about concrete measures taken in order to prevent discrimination and to work towards more equality within higher education. Earlier projects covered aspects such as course evaluation, which can be touched on in this paper only superficially. The following study should be read as one example within a longer history of developing strategies for gender inclusive policies in this specific higher education institution.

\section{Selection of interview partners}

The participants in this study were university teacher educators, who were teaching students in different subjects as well as different programmes within teacher education, from pre-school and primary education to secondary and adult education. Teacher education is located within the Faculty of Arts and Science, the Faculty of Educational Science, and the Faculty of Science and Engineering, also called the Institute of Technology.

The study is based on individual interviews and some group meetings with teacher educators. The author wrote memos about these meetings, and seven interviews were recorded, transcribed verbatim, and used for the in-depth analysis (Bryman 2008). All quotations in this article are from these individual interviews. All teacher educators with responsibility for any of the almost thirty specific subjects being taught within teacher education were informed about the study, its purpose and, later, the preliminary results.

[Table 1 near here]

Table 1: Distribution of interview partners

Programme

Primary school: 3

Secondary school: 4

Sex 
Male: 4

Female: 3

Campus

Campus 1: 2

Campus 2: 5

Faculty

Educational science: 3

Arts and science: 3

Science and engineering: 1

Table 1 shows the distribution of the interviewed university teachers according to teaching programme, sex, campus and faculty. The numbers reflect the distribution between men and women and different fields. Teacher educators were contacted by email and through regular subject meetings. All teacher educators who contacted me and agreed to participate before or shortly after the first reminder were included in the study. One subject representative within the Faculty of Science and Engineering was contacted later in order to ensure that this field of teacher education was also represented. These views will contribute exploratory findings on how university teacher educators perceive the realisation of gender inclusion.

\section{Research ethics}

The study meets the ethical requirements of the Swedish Research Council (CODEX 2010). The teacher educators were informed in writing about the purpose of the interviews and they influenced which aspects of gender inclusion were pursued in the conversations. The interview participants were informed that participation in the study was voluntary, that it was possible to suspend one's participation at any time, and that all the interview evidence would be made anonymous. 
I conducted the interviews in connection with my work as a gender lecturer at the Faculty of Education. My intention was to come into contact with the diverse group of university teachers in charge of different subjects included in teacher education and to listen to how they reflect on gender strategies within their respective subjects. I was open from the beginning, in that I aimed at evaluating strategies for gender inclusion and, as mentioned above, the teachers gave their consent for our conversations to be recorded. This might have contributed to the fact that I was mainly approached by teachers who had previously reflected on gender inclusion in relation to teaching in their respective subjects. Ethical dilemmas, however, might be associated with my function as a gender lecturer at the faculty of education [Function omitted for review purposes]. I tried to address that by sending interview transcripts to the individual university teachers interviewed, and subject representatives were the first group with whom I shared an early version of the report. This was in line with the purpose that the results of my study should contribute to a discussion within the group of university teachers at the investigated university.

It is my intention that no teacher educator who has participated in the study can be identified through the quotes or other information. Therefore, all information is treated as confidential, and personal information is made anonymous. The citations from the individual interviews are followed by capital letters with arbitrary capital characters from $\mathrm{E}$ through to $\mathrm{K}$ and the page number where it was obtained from the transcript.

\section{Method of analysis}

Qualitative data analysis is based on sorting, compressing, and organising information gathered through interviews. Interview transcripts were coded using a system of open coding according to content analysis by Johannessen and Tufte (2003). The 
results have been presented in different study groups, executive teams, and research meetings; gradually, an analysis has evolved combining in-depth analysis of the data with available knowledge from literature on gender and higher education.

\section{Results}

University teacher educators discussed the importance, as well as the possibilities, of working with gender inclusion at university level during the interviews. In the sections that follow, I will present teacher educators' strategies and dilemmas when working with gender inclusion. I will also introduce teacher educators' reflections on coping with horizontal gender segregation within teachers’ education. These parts of the interviews focussed, for example, on how teacher educators can interact with female students in male-coded fields and how male students can be attracted to female-coded areas. Finally, times of university reform seem to pose special challenges for gender inclusion in teacher education.

\section{Strategies}

Swedish universities follow general policies and also develop their own policies for gender mainstreaming. The Swedish government takes active initiatives (e.g., Swedish Presidency of the EU 2009) and the university in question wants to be a leading actor in the field (LiU 2009). The university should be a place where teaching students can experience and imitate gender-sensitive patterns of behaviour and teaching. This sentiment is expressed as a central task of university teaching:

I think that there is one area, which could be especially interesting, in fact, which is, however, not specific just for our subject, but for all subjects within the teachers' education programme. I think, the most logical part to take into account if we want to focus on a gender perspective is when we discuss students' future teaching profession. Which perspective shall I as a future teacher put on gender, 
when I am standing in my classroom? It's about awareness of gender differences and of topics like the fact that boys put themselves forward more readily than girls and so on. (I-1)

Teaching culture at the university plays an important role in relation to the competences teacher students acquire for their future teaching profession. Students will teach pupils in the near future, and what one experienced has oneself as a pupil or student often influences teaching styles. It is important that students develop an understanding of the sometimes unconscious sex-specific treatment of boys and girls by teachers. The teacher educator quoted above calls this 'awareness of gender differences' and connects the term gender perspective to distinctions in teachers' behaviour towards boys and girls and gender-sensitive teaching.

Different strategies that the participants mentioned for teaching were a variation or combination of mandatory gender content and more advanced elective elements of gender-related topics. They also referred to a need for examining gender-related content in order to show its importance to the students. Gender-related content is described as being included more or less naturally in relation to the course content as a whole.

The first thing is to be transparent in gender issues [...]. ${ }^{2}$ Initially, for example, we try to include literature by women writers as well and we also try to show the gender... relationship [...] by actually stating very clearly the first name and these things in the reading lists and such things [...], which shows the intention. It is one of these little concrete things. ... The second point, we had well... now decided on [after discussion] in various meetings, was that we had noticed and also had received comments from students to the effect that the gender chapter, which is included in some books, was not dealt with. In the 90s, gender-specific chapters or sections started to be included in textbooks. And [...] with content congestion argument, it was not used occasionally. Well... we have not tried this so hard then, but then we decided 
that we do not remove these particular passages, no. So they are prioritised in the planning and use of the book. (F-6)

This teacher educator describes the subject's policy concerning how gender issues can be addressed. Through certain formalities, such as the authors' first name being included in the reference list, it becomes apparent whether the course literature is written by male or female writers and that the gender chapter in textbooks is not to be omitted. Another informant explains that it may be difficult to find literature by women. In this case, the lack of female authors is addressed in the introductory lecture to the course as a strategy for gender inclusion.

A wide variety of positions and strategies became evident in the transcribed conversations and memos. There are examples of subjects within teacher education that demonstrate a consistent problematisation of gender, diversity, and power, which pervaded the curriculum and teaching process. However, it seems more typical that topics related to gender and equality are occasionally raised and teacher educators consider how they can actually include these in lectures, seminars, literature, or workshops, as reflected by the following quote:

But, if I think of this course, what could we include that touches on gender?... Lectures, literature seminars, workshops... what else do we have...? We have many, many different types of examinations... (E-5)

This teacher educator is concerned that gender should become a part of the content and considers where and how related topics could be included. The last part of the quote obviously aims at discussions that different forms of examination can facilitate for different student populations, men and women. 
Summarising, the interviewed university teacher educators describe a variety of gender sensitivity strategies in relation to the form of education, as well as an intention to integrate gender-related content into their lessons, for example by having reading lists with male and female authors or gender-related content in introductory lectures. Combining mandatory course content on gender and also providing opportunities for specialisation to more interested students are some of the other steps mentioned in relation to course planning. All these are strategies described earlier for gender sensitive teaching by authors like Bondestam (2004) and Fogelberg Eriksson and Karlson (2006). It is also obvious, however, that a gender perspective is not necessarily perceived as an integrated part of the teacher educators’ course planning, instead being described as a matter to be added 'on top' of the course content.

\section{Dilemmas}

Teacher educators describe dilemmas that reflect contradictory messages in relation to gender-sensitive perspectives, which can be related to ideas of gender as fluid, social structuring or essentialist, and involve risks of stereotyping (Tinkeling et al. 2003, Nyström 2007, Bondestam 2010, Lahelma 2011). The following quote comes from a self-critical statement about dealing with gender in courses within the respective subject:

I do not think that sex or gender... we do not give it much attention in the subject. (G-3)

The teacher educator continues by describing gender, in the sense of distinguishing between boys and girls, as being included in the course, but it is not clear how potential gender differences can be interpreted. 
[It is not written in the syllabus but] in the study guide and instruction, it says that it should be a girl and a boy. Just because they should be able to compare. [It is not so strictly regulated,] but then in the vast majority of the cases, it's a girl and a boy whom they follow.

I: So is there any immanent idea that it's different for girls and boys, or why one should have a girl and a boy?

Yes, it's probably partly that you still can, you should be able to take a gender perspective as well. However, it is not explicit in the data itself, but we are saying to them, that once they do this analysis, it is also about comparing the children. And clearly sometimes [something] can be explained by the fact that one is a boy and the other is a girl... (G-4)

The students of this course face the task of comparing teaching a boy to teaching a girl. However, none of the included literature problematises gender in the teaching process. Although this task might be designed for raising gender consciousness, it can also have the opposite effect. Talking about gender awareness seems to be accompanied by perspectives that focus on gender or rather sex differences. There might even be a danger of stereotyping if differences are stated but not probletamised or compared to knowledge that is theoretically grounded in gender literature.

Dilemmas related to discussions on gender perspectives in teaching are obvious. Sometimes talking about gender is avoided for fear of negative reactions:

I think we have been careful to actually write, and perhaps wary of how should I say, just use terms that sometimes people can re act strongly to. I would rather talk about male and female perspectives than talk about a gender perspective. (I-9)

The supposed strategy here is to avoid the whole term "gender" and return to talking about men and women and their respective perspectives. There are other voices problematising differences, which are described as typical for boys' or girls' schooling: 
... today you will experience very little of what it is like in the traditional school. That we have a number of boys or men who are so forthcoming [in the classroom]... I don't think at all that it's like that today. If there are activities or if one should answer a question or just say something, then women are just as active as men. So there are no such structures which are so clear. However, there is also a certain selection... our best students are often women... Generally studious and diligent... Guys often make themselves kind of scarce... this often makes them feel better anyway [laughing]. (H-7)

This teacher educator contradicts the view that it is mainly men who are more prominent in the classroom and states that women are just as active. However, s/he continues by describing women as efficient and diligent, and men as the ones who take a more relaxed approach. Although the teacher educator contradicts gender stereotypes of certain behavioural patterns, s/he states in the same context how s/he experiences women and men as students.

All teacher educators have, in the course of gender mainstreaming, a responsibility for taking gender inclusion into account when planning and conducting their courses. Gender mainstreaming is actively practiced and some of the policies come up during the interviews. Some teacher educators were interested in participating in the interviews after receiving negative feedback from students, while the directors of study encouraged others:

In conversations with the director of studies, we have looked at the course evaluation we did last spring... and... we have very good course evaluations... The course is rated as 4.5 out of a possible 5 . But there was this kind of mandatory question, if the students have been discussing gender issues and this was always low in both my course and the sister course. (E-1)

This quote relates to an earlier practice where all centrally administered course evaluations included a question on gender perspective, a policy that had continued for a 
few years. By now, such policies have been changed. As part of the trend of gender mainstreaming, a statement 'The course is conducted in such a way that both men's and women’s experience and knowledge is made visible' has been included under all curricula.

And it is exactly this that is included in all courses. 'The course is conducted in such a way that both men's and women's experience and knowledge is made visible,' that's what we have written.

(I) Well, is it such a standard sentence that comes in each...

Yes, because that's what we really not should miss and I must say, there are quite a few different aspects being covered here, it’s like an umbrella. (I-9)

We can see an identification with regard to evaluation policies but, at the same time, the top-down process can also be experienced as bothersome and as leading to resistance:

This fact that people are constantly debating, 'now let's take a gender perspective, now let's talk about gender,' it becomes easily a backlash, it’s sort of, you feel overwhelmed by this and for those who do not recognise themselves completely in this, in the end it will turn you away and you will fight it tooth and nail. (I-9)

Many of the topics seem to include room for similar dilemmas in between support for gender sensitive strategies and elements of resistance. For example, this can be seen when teacher educators talk about the practical part of teacher training:

... it would actually be possible to include gender [in the practical part of the studies]

$[\ldots]$

... Because I do not think at all that they like, yes, it has been up at university level so much, I mean they might not have discussed it so much in the schools. (G-16)

This quotation can be interpreted as an encouragement for all actors to cooperate, bringing together the theoretical parts of studies at the university with the practical parts 
at school, and also in relation to including a gender perspective in teaching. However, it could also be interpreted as a kind of resistance, stating that now one has worked so much with this field at the university, it is time for the schools to work with gender sensitive teaching.

The interviews highlighted a variety of dilemmas, which so far are reflected upon too little in international research. Dilemmas and also resistance against top-down policies become evident. Talking about gender inclusion often leads to reasoning about gender differences and a polarisation of gender dichotomies, which reflect a society's gender contract (Hirdman 2007). Returning to talking about male and female perspectives includes a risk of essentialism, which gender studies aim to avoid. Teaching students about specifics of boys and girls in the classroom embraces risks of stereotyping when insufficiently grounded in gender research (Lahelma 2011). The results also show that the structure of men and women as students is under a constant process of construction and reconstruction (Butler 1990), and university teachers are important actors in this process of doing gender. Recent projects show that dichotomies between men and women live on in Swedish teacher education and the terms "gender" and "gender equality" are applied in a highly diverse manner (Bondestam 2010, Hedlin and Åberg 2011b). University teacher educators need continuous opportunities for reflexive exchange to live up to the gender-mainstreaming demands placed onto them and to cope with dilemmas like those described above.

\section{Horizontal gender segregation}

Different parts of teacher education recruit different student groups. Although horizontal gender segregation and especially the need to attract men to teacher education is a prominent topic (Mills, Martino, and Lingard 2004; HSV 2009), breaking up the feminisation of teacher education is not going to be an easy job (Murray and 
Maguire 2007). However, feminisation is a more severe problem for some sectors of teacher education, especially for teachers working with younger children. In other fields there is a more balanced distribution of men and women, or we could say that patterns of segregation and exclusion are more complex.

According to society's gender contract ${ }^{3}$, men and women should work in different sectors and do different things. Professions are thus defined as either work for women or work for men. This is shown in the varying number of female and male teachers in different school subjects and at different levels in the educational hierarchy (Hjalmarsson 2009, 158).

In the target group of this study, representatives of different subjects in both primary and secondary education, slightly more of the teacher educators are men at the university investigated. There are subjects in which almost only women are working and studying, while there are others that consist primarily of men in higher qualified and permanent positions:

And the university teachers working in our subject are of course only permanently employed males... (F-9)

This teacher educator describes a classic power relation, with more men in secure university employment. So although teacher education is generally described as a feminised field, male dominance structures, which are typical of higher education (Husu 2000; HSV 2005), and vertical gender segregation prevail. However, vertical gender segregation was not a dominant topic in the interviews. Teacher educators seemed much more concerned with horizontal segregation within and between different subjects of teachers' education and its consequences.

Intersections of teacher educators' and students' gender and generation In intersections with other social categories (de los Reyes and Mulinari 2005), like 
generation, gender plays an important role when it comes to understanding interaction within teacher education programmes (Reimers 2006).

A predominance of men in certain subjects can make it difficult for women's needs to be met. One male teacher educator mentions fear of being accused of being sexist when commenting on a teacher student's outfit not being appropriate in a certain context, something he expects to be easier for a woman to mention. A female teacher educator describes how women, both as teacher educators and students, dominate her subject:

We are many women who teach, yes now this year we really basically just have been women who have been teacher educators, we have had some male lecturers and so sometimes [...]. But especially now when we are actually a few women who are a bit older and then these young guys they're almost [young enough to be] our sons, then, and it's easy as that...

$[\ldots]$

I mean, how will this affect us in our professionality? Especially when we really need to be professional.

$[\ldots]$

Do we place the same high demands on these guys when it comes to awarding an A grade, for example? (G-5)

The relationship between teacher educator and student is problematised in the quote above, in relation to both generation and gender. There are few men who study in this subject, and male students are encouraged to continue their studies. The quotation reflects teacher educators' worries that this may affect grading. A man noticed a similar problem in relation to women as pupils or students: 
... Beautiful girls often get good grades. That's shown in some research, and things like that I remember, and [...] well what can that depend on? ... One has definitely thought about these things. (I-1)

Both teacher educators refer to the need for a further discussion on teaching students of the opposite sex, for example in critical situations relating to grading, especially if the student belongs to an underrepresented group in the subject. Difficulties of acting in a way that is gender-neutral were often described, exemplifying what Lahelma (2011) mentions as one of the problems of gender inclusion in teachers' education. Teacher educators state that some topics can be difficult to discuss between men and women, and they point out that grading in particular needs to be discussed further in relation to gender. The university has adopted a policy that examination should be anonymous in order to prevent discrimination. While this works well for written tests, gender and other personal features remain obvious in practice observations and all forms of course work requiring direct feedback.

\section{Perceptions of strategies to balance gender dichotomies}

Talking about gender inclusion often leads to reasoning about gender differences and a polarisation of gender dichotomies (Bondestam 2010), which reflect a society's gender contract (Hirdman 2007). Research has shown that all kinds of disciplines can be adapted to the learners' needs (Palmer 2009), but natural sciences and mathematics are usually described as gender-neutral.

My subject is..., it [depends on] laws in natural science, we are not discussing philosophy. Yes, of course we could do that, but this is not priority number one. [...] The subject is not related to sex or gender [...] From a social science perspective that might be interesting, but then we are talking about science history. [...] There would be much to be taught about that (from a gender perspective), but it is nothing students need to learn in relation to what they will be teaching at school. [...] That is what controls teacher education. (K-2-3) 
This university teacher describes the subject - at least in the way it is usually taught in teachers' education - as gender neutral. There are other priorities, which determine what has to be taught at university and the connection to teacher education complicates things even further as it reduces the curriculum to what is expected to be useful for teachers. Gender content and more philosophical questions are, in the best case, integrated into non-obligatory tasks.

There are, however, also other examples of teacher educators developing specific strategies for balancing gender dichotomies in teachers' education. Attracting men to female-coded subjects is described as a question of reaching new student groups by adapting the context of teaching:

A majority of our students have always been and are always going to be women. [...] And also in the group of teacher educators, middle-aged and a bit over middleaged women are clearly overrepresented. [...] And if we want to attract new students, we should include a new group of students, and by this we could also get in more men into the courses. (I-3)

The teacher educator in the above quote continues to describe how the content of humanistic subjects could be broadened to include what is believed to be of interest to men, such as tension, business and technology. In order to attract men to female-coded subjects, the content should be tailored to men's interests. On the other hand, women in male-coded subjects were described in connection with a fear that could be overcome:

\section{[...] they said in the beginning they} were very sceptical of [our subject], they had felt that it was not their area. They had a picture from school that was, that they were fright ened, it was not theirs, it was not their field at all, but yet, they felt it was pretty fun once they had entered it here. They have changed their opinions. They felt that yes, they could enter the field and they felt 
it was something that they could work with then, with young children and all of this. When they'd met them, it would perhaps even be fun to get them interested. Because it was important, they felt that they had an important mission to communicate this. (J-4)

This quote is with regard to a comprehensive subject for future primary school teachers. For this informant, it was important to get everyone interested in the subject and to convey confidence and a feeling that the subject itself is fun. Therefore, the teacher educator feels that the students' earlier approach, which may also relate to gender, must be processed and developed.

The results from this study showed that some subjects are described as gender neutral while others are identified as gender coded. Some respondents perceive that in order to attract men to female-coded subjects, content should be tailored to men’s interests whereas women in male-coded subjects were described in connection with a fear that could be overcome. Although these strategies are aimed at balancing horizontal gender segregation and the gender dichotomies, which reflect society's gender contract they are, according to Bromseth (2010), in danger of reproducing heteronormative patterns. While teacher educators were willing to search for new content to attract men to female-coded fields, the focus when they met women in male-coded fields was on adapting the women's relationship to the subject.

\section{Gender inclusion in times of university reform}

Teacher education anticipated a major national re-organisation when this study was conducted. There is obviously not much relevance seen in working with the old curriculum:

... please just get in touch later on, in a year or so, and see what we have done, what ideas we have followed and what ideas we have not followed. Now of course the new teacher programme will come... (E-24) 
The quote reflects an intention towards change and development, but it is also evident that the changes of the overall structure and the content of teachers' education overshadow the ordinary pattern of course development:

It's not worth doing something absolutely new, because the courses are only running one more time and then everything will be completely different. But when we write these... the new, uh... the new curriculum or whatever we should call it, we will also revise the course content in a good way (H-11).

An ambivalence to change becomes evident in relation to the present and the future type of teacher education. While the old teachers' programme is being phased out, not much value is seen in working with developing courses. Research literature points to the importance of also taking gender into account in times of reforming education programmes (Fogelberg Eriksson and Karlson 2006), and obviously university reforms are a perfect time to establish new patterns of gender inclusion.

\section{The complexity of the gendered nature of teachers' education}

This study revealed that teacher education is not only, as described earlier, a highly feminised field (Maguire and Weiner 1994; Dillabough and Acker 2002; Murray and Maguire 2007), it is also a discipline that is permeated by horizontal and vertical segregation related to gender pattern in higher education (Husu, 2001). In order to better understand and hopefully challenge the gendered nature of teachers' education, further analysis is necessary according to Weiner (2002), and that is what this study intended to do by exploring how university teacher educators experience and deal with the consequences of this segregation. The results of this study provide an insight in the structure of gender in teacher education and the consequences of horizontal gender segregation in higher education. In line with EGGE (2009), the study contributes an 
investigation into the internal practices in higher educational organisations with the aim of developing new ideas of structural preconditions for desegregation and introduces the pedagogical tool of gender inclusion in combination with the more political administrative forms of gender mainstreaming.

\section{A long way to desegregation}

International studies of gender segregation in employment suggest that rising numbers of female employment often lead to strong gender segregation at first, which can be slowly followed by desegregation (Anker 1997; Bielby and Reskin 2005). Using the example of one university which is devoted to gender equality, this study explores how complex this process can be. The findings broaden our understanding of horizontal gender segregation and exclusion in higher and teachers' education. The data indicate that vertical segregation with more men in secure positions and higher up in the university hierarchy is also prevalent in teachers’ education. Furthermore, horizontal gender segregation becomes obvious between different academic fields that are part of teachers' education. The pattern within teacher education follows the distribution described for university education in general (Husu 2000; HSV 2005), with more men in technical fields and more women in caring subjects. Patterns of exclusion are, however, complex. In teachers' education, a gender-specific distribution of labour is highly congruent with what has been described by Hirdman $(1988,2007)$ as 'society's gender contract'.

Obviously, there is a long way to go to desegregate different university education fields. We know from international school studies like PISA that female students in Sweden compete as well and perform better not only in reading but also in mathematics (Nyström 2009; EGGE 2009), a field which is traditionally regarded as male-coded. We also know, both from the practical work and from a wide range of 
studies, that men are reluctant to enter teacher education for younger pupils and preschool education (Mills, Martino and Lingard 2004; HSV 2009). Education statistics for Sweden show some desegregating trends, with caring subjects in upper secondary schools no longer being a female-only field as it used to be three decades ago. In technical fields we do not, however, see a similar increase in opportunities for women (Sandell 2007).

The results from the present study gave examples from the internal work of teacher education. In the data, we explored qualitative examples of how university teacher educators try to open up their subjects across gender borders. Teacher educators were more likely to open up a female-coded subject for men, while women were still in danger of being seen as deviant in male-coded fields. The approaches described seem thereby to be shadowed by heteronormative patterns (Hjalmarsson 2009), with trends to support women in male-coded fields psychologically, while there is a readiness to adapt subjects to what is perceived as male interests and needs. This gives an impression that men are also being privileged in teachers' education while women are at risk of being perceived as deviant and needing to adapt their position to the subjects or topics to be mastered. This could possibly provide an explanation to why some academic fields remain closed to women despite school students showing good competences in corresponding fields. With this result, the study contributes - with its investigation into the internal work of teacher education - a better understanding of structural preconditions and thus provides important knowledge for the continued process of desegregating teacher education and higher education.

\section{Gender inclusion as pedagogical tool}

Finally, on the basis of this study, we might want to discuss further implications for policy and professional development in teacher education. This study showed how 
gender is constantly constructed and reconstructed in teacher education. Hedlin and Åberg (2011b) describe university teacher educators as missing valuable opportunities to problematise parallel existing ideas of gender and gender equality that draw on biological, normative, and individualised views of the respective concepts. The present study exemplified how university teacher educators and students frequently relate to dichotomised perspectives of boys and girls, men and women, and that imperfectly mediated approaches to gender sensitive teaching can strengthen that tendency. Universities need to develop strategies, whereby university teachers in general and teacher educators in particular can individually and collectively challenge gender concepts and practices that permeate university teaching.

The relevance of gender knowledge has been claimed for teacher education reforms for over two decades in Sweden (SOU 1999; SOU 2008), but we still need to integrate this perspective more thoroughly in order to overcome simple dichotomisation between men and women. University reforms are both favourable, in order to incorporate gender perspectives more fully and appropriately (Fogelberg Eriksson and Karlson 2006), and risky times, insofar as we might lose what we have been working towards for decades. Gender inclusion is not stable - it is a process in need of continuous efforts.

Gender inclusion is, as mentioned earlier, a pedagogical tool which is based on the perspectives and involvement of all actors. Its aim is to realise gender equality through the participation of all actors and ongoing reflections for competence development. It can be seen as a fruitful addition to the political tool of gender mainstreaming. Some moderate steps taken by the university observed are that all institutions taking care of parts of the different teacher education programmes have to engage in integrating a gender perspective into their curriculum. Future studies have to 
show which results can be developed when top-down policies are consequently combined with university teachers' involvement when developing strategies for gender inclusion. Gender distribution in all new programmes from pre-school teachers to upper secondary school teachers and in selected subjects is being monitored for both students and actively engaged teacher educators. The inclusion of gender topics in syllabuses, course literature, and examinations is another matter of concern to be followed up. This will hopefully give more evidence for a further development of gender equal teachers' education. It cannot, however, replace a process of continuous monitoring of teacher

educators’ and students’ perceptions of gender inclusion. Obviously, politically oriented gender mainstreaming and pedagogically induced gender inclusion should be combined meaningfully with the common aim of perceiving gender equality in higher education.

\section{Notes}

1. Author's calculation according to statistics available via http://www.skolverket.se/statistikoch-analys/statistik/2.4391/2.4393.

2. A $[\ldots]$ signifies the omission of parts of the quote; ... represents a pause during talking. 3. Hirdman $(1988,2007)$

\section{References}

Anker, Richard. 1997. Theories of occupational segregation by sex: An overview. International Labour Review, 136(3): 315-339.

Arnesen, Anne-Lise, Elena Lahelma and Elisabeth Öhrn. 2008. Travelling discourses of gender and education: The case of boys' underachievement. Nordisk Pedagogik 28: 1-9.

Bettio, Francesca. 2008. Occupational segregation and gender wage disparities in developed economies: Should we still worry? in Francesca Bettio and Alina Verashchagina (eds). Frontiers in the Economics of Gender, Routledge Siena Studies in Political Economy, Routledge: 267-285. 
Bielby, Denise D. and Barbara F. Reskin. 2005. A sociological perspective on gender and career outcomes. Journal of Economic Perspectives, 19(1): 71-86.

Bondestam, Fredrik. 2004. Könsmedveten pedagogic för universitets- och högskolelärare. Stockholm: Liber.

Bondestam, Fredrik. 2010. Kunskap som befrielse? En metaanalys av svensk forskning om jämställdhet och skola 1969-2009. Stockholm 2010. SOU 2010-35.

Bridges, William P. 2003. Rethinking gender segregation and gender inequality: Measures and meanings. Demography, 40(3): 543-568.

Bromseth, Janne. 2010. Förändringsstrategier och problemförståelser: från utbildning om den andra till queer pedagogik. In Normkritisk pedagogic. Makt, lärande och strategier för förändring, ed. Janne Bromseth and Frida Darj. Uppsala, Centrum för Genusvetenskap: 27-50.

Brownhill, Simon. 2010. The "brave" man in the early years (0-8): The ambiguities of the "role model". Paper presented at the British Educational Research Association Annual Conference, University of Warwick, 1-4 September 2010, http://www.leeds.ac.uk/educol/documents/193285.pdf (accessed 20120906)

Bryman, Alan. 2008. Social research methods. Oxford: Oxford University Press.

Butler, Judith. 1990. Gender trouble. Feminism and the subversion of identity. London, New York: Routledge.

Carlberg, Mia and Fredrik Bondestam. 2010. Svensk forskning om skola och jämställdhet 1969-2009. En bibliografi. SOU 2010:36.

CODEX. 2010. The Swedish Research Council's rules and guidelines for research. www.codex.uu.se/en/forskningsetik.shtml.

Connell, R.W. 1995. Masculinities. Cambridge: Polity Press.

de los Reyes, Paulina and Diana Mulinari. 2005. Intersektionalitet. Kritiska reflektioner över (o)jämlikhetens landskap. Malmö: Liber.

Dillabough, Jo-Anne and Sandra Acker. 2002. Globalisation, women’s work and teacher education: a cross-national analysis. International Studies in the Sociology of Education, 12, no. 3: 227-260.

EGGE European Commission’s Expert Group on Gender and Employment. 2009. Gender segregation in the labour market. Root causes, implications and policy responses in the EU. EC. Luxembourg: Publications Office of the European 
Union. (ec.europa.eu/social/BlobServlet?docId=4028\&langId=en, accessed 06092012)

Erixon Arreman, Inger. 2005. Att rubba föreställningar och bryta traditioner. Forskningsutveckling, makt och förändring i svensk lärarutbildning. Umeå universitet: Doktorsavhandlingar i Pedagogiskt arbete Nr 3.

Erixon Arreman, Inger and Gaby Weiner. 2007. Gender, research and change in teacher education: A Swedish dimension. Gender and Education, 19, no. 3: 317-377.

Eurydice. 2010. Education, Audiovisual and Culture Executive Agency (EACEA P9): Gender Differences in Educational Outcomes: Study on the Measures Taken and the Current Situation in Europe. www.eurydice.org.

Fogelberg Eriksson, Anna and Ingrid Karlson. 2006. Att integrera genus som innehåll och form. En rapport om genusintegrering av högskoleundervisning. Slutrapportering av GrundSipa-projektet. Linköping: Linköpings universitet. www.liu.se/genus/projekt (last accessed: 2011-07-17).

Hedlin, Maria and Magnus Åberg. 2011a. Teacher education challenges gender Mapping and changing gender patterns in ten months. Presentation at NERA's 39th congress. Rights and education. 10-12 March, University of Jyväskylä.

Hedlin, Maria and Magnus Åberg. 2011b. Lärarutbildningen, jämställdhet och genus. Linnéuniversitet. Växjö: Repro.

Henwood, Karen L. 1997. Qualitative inquiry: perspectives, methods and psychology. In John T. E. Richardson (Ed.). Handbook of Qualitative Research Methods for Psychology and Social Sciences. Leicester: BPS Books, 25-40.

Hirdman, Yvonne. 1988. Genussystemet. Reflectioner kring kvinnors sociala underordning. Kvinnovetenskaplig tidskrift. 9, no. 3: 49-64.

Hirdman, Yvonne. 2007. Gösta och genusordningen. Stockholm: Ordfront.

Hjalmarsson, Maria. 2009. Lärarprofessionens genusordning. En studie av lärarnas uppfattningar om arbetsuppgifter, kompetens och förväntningar. Ph.Diss. University of Gothenburg. Acta Universitatis Gothoburgensis.

HSV Swedish Agency of Higher Education. 2005. Dold könsdiskriminering på akademiska arenor - osynligt, synligt, subtilt. Rapport 2005:41 R, Stockholm: Högskoleverket.

HSV Swedish Agency of Higher Education. 2009. Man ska bli lärare. Man ska bli lärare! Den ojämna könsfördelningen inom lärarutbildningen - beskrivning och analys. Stockholm. Högskoleverkets rapportserie 2009:7 R. 
Husu, Liisa. 2000. Gender discrimination in the promised land of gender equality. Higher Education in Europe XXV: 2, 221-228.

Husu, Liisa. 2001. Sexism, support and survival in academia. Academic women and hidden discrimination in Finland. University of Helsinki, Social psychological studies 6.

Johannessen, Asbjørn and Per Arne Tufte. 2003. Introduktion till samhällsvetenskaplig metod. Malmö: Liber.

Kvale, Steinar and Svend Brinkmann. 2009. Den kvalitativa forskningsintervjun. Lund: Studentlitteratur.

Lahelma, Elina. 2005. School Grades and Other Resources: The 'Failing Boys' discourse revisited. NORA, Nordic Journal of Women's Studies 13, no. 2: 78-89.

Lahelma, Elina. 2006. Gender Perspective: A Challenge for Schools and Teacher Education, In Research-based Teacher Education in Finland - Reflections by Finnish Teacher Educators, ed. R. Jakku-Sihonenand and H. Niemi. Research in Educational Sciences 25. Turku: Painosalama, 153-162.

Lahelma, Elina. 2011. Integrating Gender Awareness into Finnish Teacher Education: an impossible mission? Education Inquiry, 2/2011 also: Presentation in Jyväskylä 9 March 2011.

Lenz Taguchi, Hillevi. 2005. Getting Personal: how early childhood teacher education troubles students’ and teacher educators’ identities regarding subjectivity and feminism. Contemporary Issues in Early Childhood, 6, no. 3: 244-255.

LiU. 2009. Linköping University: Equality in practice. Gender Mainstreaming of Undergraduate and Graduate Education 2007-09 (Adopted by the Rector of Linköping University, Mille Millnert, on 23 November 2006).

LiU. 2010a. Speaking of women and men at Linköping University. Employee and student statistic 2010. www.liu.se/likavillkor/statistik.

LiU. 2010b. Gender lectureship at Linköping University. A model for gender mainstreaming in higher education. www.liu.se/genus/om-genuslektorerna?l=en.

LiU. 2011. Linköping University: The Equal Opportunities Strategy and Action Plan for 2011 (Dnr LiU-2010-01407, Adopted by the University Board on 29 November 2010). 
Lykke, Nina. 2009. Genusforskning. En guide till feministisk teori, metodologi och skrift. Stockholm: Liber.

Lykke, Nina. 2010. Lärarutbildningen - för män med engagemang för jämställdhet. 2010-03-29. Founded by Delegationen för jämställdhet i högskolan.

Maguire, Meg and Gaby Weiner. 1994. The place of women in teacher education. Discourses of power, Educational Review, 46, no. 2: 121-139.)

Mills, Martin, Martino, W. and Lingard, B. 2004. Attracting, retailing and retaining male teachers: policy issues in the male teacher debate. British Journal of Sociology of Education, 25, no. 3: 355-369.

Murray, Jean and Meg Maguire (2007). Editorial: Changes and continuities in teacher education: international perspectives on a gendered field. Gender and Education, 19, no. 3: 283-296.

Nyström, Eva. 2007. Talking and Taking Positions. An encounter between action research and the gendered and racialised discourses of school science. Umeå University (Ph.D. thesis; Pedagogiskt arbete; 16).

Nyström, Eva. 2009. Nordisk forskning om genus och jämställdhet $i$ skola och utbildning: 2005-2009. NIKK.

Öhrn, Elisabeth. 2002. Könsmönster i förändring? - en kunskapsöversikt om unga i skolan. Stockholm: Skolverket.

Palmer, Anna. 2009. 'I am not a "Maths-person.”' Reconstituting Mathematical Subjectivities in Aesthetic Teaching Practices. Gender and Education 21, no. 4: 387-404.

Reimers, Eva. 2006. “Always somewhere else - heteronormativity in Swedish teacher training.” In Norms at Work. Challenging Homophobia and Heteronormativity, ed. Lena Martinsson, Eva Reimer, and Jolanta Reingarde. Stockholm: Under Ytan, 54-68.

Sandell, Anna. 2007. Utbildningssegregation och självsortering. Om gymnasieval, genus och lokala praktiker. Malmö: Malmö University. Doctoral dissertation.

SOU. 1999. Att lära och leda. En lärarutbildning för samverkan och utveckling. Lärarutbildningskommiténs slutbetänkande. Stockholm: SOU 1999:63.

SOU. 2008. En hållbar lärarutbildning. Betänkande av Utredningen om en ny lärarutbildning (HUT 07) Stockholm: SOU 2008: 109.

Swedish Presidency of the European Union. 2009. Conference: Gender Differences in Educational Achievement, 17-18 November 2009, Uppsala, Sweden. 
Tinklin, Teresa, Linda Croxford, Alan Ducklin, and Barbara Frame. 2003. Inclusion: A gender perspective. Policy Futures in Education, 1, no. 4: 640-652.

Weiner, Gaby. 2002. Uniquely Similar or Similarly Unique? Education and development of teachers in Europe. Teaching Education, 13, no. 3: 273-288.

Wernersson, Inga and Hildur Ve. 1997. Research on gender and education in the Nordic countries. Scandinavian Journal of Educational Research, 4: 295-317.

Wernersson, Inga. 2006. Genusperspektiv på pedagogic. Stockholm: HSV.

[Four references were omitted in this version for review purposes.] 
${ }^{1}$ Author's calculation according to statistics available via http://www.skolverket.se/statistikoch-analys/statistik/2.4391/2.4393

${ }^{2}$ A [...] signifies the omission of parts of the quote; ... represents a pause during talking.

${ }^{3}$ Hirdman 1988, 2007 